\title{
In vitro Regeneration and Biohardening of Soybean (JS335) Variety
}

\author{
C. Janani ${ }^{1}$, B. D. Ranjitha Kumari ${ }^{2} *$ \\ ${ }^{1}$ Research Scholar, Department of Plant Science, Bharathidasan University, Tiruchirappalli 620 024, India \\ ${ }^{2}$ Professor, Department of Plant Science, Bharathidasan University, Tiruchirappalli 620 024, India
}

\begin{abstract}
An efficient protocol for in vitro regeneration of half seed explant with embryonic axis of soybean and biohardening of in vitro regenerated plantlets were standardized. For organogenesis, MS medium supplemented with cytokinins BAP (15 $\mu M)$ and TDZ (15 $\mu M)$ in combination with NAA $(1,5$ and $10 \mu M)$ or IBA $(1,5$ and $10 \mu M)$. Among the concentrations, TDZ $(15 \mu M)+N A A(10 \mu M)$ was found to be best for highest percentage (86\%) of shoots as well as the maximum number of shoots $(20.6 \pm 0.88)$ and length of shoots $(9.0 \pm 0.78 \mathrm{cms})$. The best response for maximum number of roots $(18.6 \pm 0.88)$ with root length $(2.9 \pm 0.18 \mathrm{cms})$ was noticed in the combination of TDZ $(15 \mu M)$ with IBA $(5 \mu M)$. The plantlets were transferred into the papercups and inoculated with Bacillus subtilis to enhance the survival of regenerated plantlets. The maximum survival $(85 \%)$ was recorded in the plantlets treated with $B$. subtilis $(0.6)$ of Optical Density at $600 \mathrm{~nm}$ with maximum number of shoots $(26.0 \pm 0.7)$ and length of shoots $(21.0 \pm 0.5 \mathrm{cms})$ and maximum number of roots $(12.3 \pm 0.4)$ and root length $(2.7 \pm 01 \mathrm{cms})$ when compared with untreated plantlets. This protocol may be used in mass multiplication of elite soybean genotypes through tissue culture and genetic transformation studies.
\end{abstract}

Keywords: micropropagation, in vitro regeneration, biohardening, half seed with embryonic axis, Bacillus subtilis.

\section{Introduction}

Soybean (Glycine $\max$ (L.) Merrill) is one of the most important crops in the world and is generally recognized as the most economical source of food protein. Plant Growth Regulators (PGR) have been used in regeneration of plants via organogenesis. Cytokinin, 6-benzylaminopurine (BAP) was commonly used PGR for miropropagation of plants. First study on organogenesis was reported from cotyledonary explants derived from germinated soybean seedling (1). BAP was efficient for multiple shoot formation from half seed explants (2) and TDZ was efficient for indirect organogenesis from half seed explants (3). BAP in combination with indole butyric acids (IBA) was used for improved regeneration frequency from embryonic axes (4) and cotyledonary node $(5,6)$.

The transfer of in vitro raised plantlets to ex vitro conditions is one of the most critical factors in the micropropagation process and cause of higher production costs. High mortality is often observed upon transfer to ex vitro conditions as the cultured plants have non functional stomata, weak root system and poorly developed cuticle. In order to increase growth and reduce mortality in plantlets at the acclimatization stage, introduction of beneficial sterile endophytic bacteria was most ideal. Both Gram negative and Gram positive strains of endophytic bacteria can be applied in this system (7). Application of bacteria is probably most effective for endophyte-free materials, where niches can still be colonized by the introduced endophyte with relatively low competition from naturally present endophytes (7). Application of endophytes at the nursery stage on tissue cultured clones in order to allow the establishment of the microbes prior to transplanting to the field (8).

Biohardening has been reported to enhance the field survival by promoting growth of the host plant and formation of secondary metabolites related to plant defence (9). The biohardening of in vitro raised gladiolus plantlets (10) and banana (11) for enhanced survival. The previous reports were available where Bacillus bioformulation could survive up to one or more year in several bioformulations (12). Carrier based preparations of two PGPR, viz., B. subtilis and Pseudomonas corrugata developed in five formulations were also evaluated for their growth promotion, rhizosphere colonization and viability under storage (13). Four bacterial isolates, Bacillus subtilis and Bacillus sp. (associates of established tea rhizosphere), Pseudomonas corrugata 1 and $P$. corrugata 2 (associates of young tea rhizosphere) were used as test inoculants and the bacteria were selected on the basis of strong antifungal activity against several fungi including pathogens of tea (14). The present study was aimed to standardize the protocol for in vitro regeneration and for the enhancement of the survival of in vitro regenerated soybean through biohardening using Bacillus subtilis.

\section{Materials and Methods}

\section{1) Source of Explants}

Soybean variety of JS335 seeds were obtained from the IARI, New Delhi the half seed explant with embryonic axis was used to standardize. The seeds were surface sterilized by detergent and washed with sterile distilled water. Seeds were soaked in sodium hypochlorite solution (4\%) for 4 hours and washed thrice with sterile distilled water.

\section{2) In vitro Regeneration}

The half seed explants with embryonic axis were separated and inoculated on MS medium fortified with TDZ $(15 \mu \mathrm{M})$ and BAP $(15 \mu \mathrm{M})$ in combination of NAA $(1,5$ and $10 \mu \mathrm{M})$ and $\operatorname{IBA}(1,5$ and $10 \mu \mathrm{M})$ for regeneration of plantlets. The cultures were incubated at $25 \pm 2^{\circ} \mathrm{C}$ with $16 \mathrm{~h}$ photoperiod.

\section{3) Biohardening}

Plantlets were transferred into the papercups with sterile sand and soil in the ratio of $1: 1$ for hardening. Before 


\section{International Journal of Science and Research (IJSR) \\ ISSN (Online): 2319-7064}

Index Copernicus Value (2013): 6.14 | Impact Factor (2015): 6.391

hardening, plantlets were inoculated with Bacillus subtilis (0.6-1.0) of OD at $600 \mathrm{~nm}$ to enhance the survival of plantlets. After 20 days, growth of hardened plantlets was studied. The data were statistically analyzed by using one way Annova with three replicates.

\section{Results and Discussion}

Among the concentrations of NAA and IBA (1, 5 and 10 $\mu \mathrm{M})$ in combination with BAP $(15 \mu \mathrm{M})$ and TDZ $(15 \mu \mathrm{M})$, the best response of regeneration frequency $(86 \%)$, number of shoots $(20.6 \pm 0.88)$ with length of $9.0 \pm 0.78 \mathrm{cms}$ was noticed in the concentration of TDZ $(15 \mu \mathrm{M})+$ NAA $(10$ $\mu \mathrm{M}$ ) for multiple shoot induction (Table 1). In rooting, the highest number of roots $(18.6 \pm 0.88)$ were noticed in the concentrations of TDZ $(15 \mu \mathrm{M})$ with IBA $(5 \mu \mathrm{M})$ with the mean length of roots $(2.9 \pm 0.18 \mathrm{cms})$ (Fig. 1). TDZ is considered to be one of the most active cytokinin for shoot induction in plant tissue culture (15). TDZ was responsible for higher regeneration capacity and multiple shoot formation efficiency than $\operatorname{BAP}(15,16)$. Regeneration frequency and number of shoots depends upon the cytokinin concentration and explant interaction, both BAP and TDZ are most effective cytokinins for shoot organogenesis in soybean (17).

The rooted plantlets were transferred into papercups containing sterile sand and soil in the ratio of $1: 1$ for hardening. The maximum survival of $85 \%$ of plantlets was recorded in the plantlets treated with Bacillus subtilis (0.6) of optical density at $600 \mathrm{~nm}$ as compared to the control $(55 \%)$ (Table 2). The maximum number of shoots (26.0 \pm 0.7$)$ with length of shoots $(21.0 \pm 0.5 \mathrm{cms})$ and the number of roots $(12.3 \pm 0.4)$ with root length $(2.7 \pm .01 \mathrm{cms})$ of biohardened plantlets was significantly higher than the controls (Fig. 2).

The ultimate success of micropropagation depends on the ability to transfer plants out of culture on a large scale at low cost with high survival rates. The in vitro grown plantlets are unable to compete with soil microbes and could not cope with the environmental conditions while transferred into the field, (18). The plant growth promoting rhizobacteria were used in the bio priming of the micro propagated banana showed increased growth of the root length, internode diameter and number of leaves (19). Likewise plantlets inoculated with Glomus fasciculatum and mixed AMF observed that flowering early and high yield in Chrysanthemum (20).

Application of the microbes is strongly recommended at the nursery stage on tissue-cultured clones in order to allow the establishment of endophytes prior to the transplanting to the field (21). In the present study, regeneration protocol may be highly useful for the production of planting material with short duration. The hardening process and plantlets for better establishment, survival, improved growth and yield of plants, which translates to higher profits for farmers. The results indicate that the biologically hardened plants were enhanced the survival of plants than the controls.

\section{References}

[1] Cheng T Y, Saka T, Voqui-Din T H. (1980). Plant regeneration from soybean cotyledonary node segments in culture. Plant Sci. Lett. 19 91-99.

[2] Paz M M, Martinez J C, Kalvig A B, Fonger T M and Wang K. (2006). Improved cotyledonary node method using an alternative explant derived from mature seed for efficient Agrobacterium-mediated soybean transformation. Plant Cell Rep., 25 206-213.

[3] Janani C and Ranjitha Kumari B D. (2013). In vitro plant regeneration from cotyledonary node and half seed explants of Glycine max L. (JS 335). Annals of Biological Res. 4 (11). 60-66.

[4] Liu H K, Yang C, Wei Z M. (2004). Efficient Agrobacterium tumefaciens mediated transformation of soybeans using an embryonic tip regeneration system. Planta 219 1042-1049.

[5] Ma X H, Wu T L. Rapid and efficient regeneration in soybean [Glycine max (L.) Merrill from whole cotyledonary node explants. Acta Physiol Plant 30 (2008) 209-216.

[6] Verma K, Rani A, Saini R. (2009). Direct organogenesis and plantlet regeneration from cotyledonary node of Indian soybean [Glycine max (L.) Merrill cultivars. Soybean Res 7 8-15.

[7] Van Vuurude JW, Elvira-Recunenco M. (2000) Endophyte management as a tool to optimize plant quality in proc of the $5^{\text {th }}$ international PGPR workshop, (Auburn University, Auburn).

[8] Ting ASY, Meon S, Kadir J, Radu S, Singh G. (2008). endophytic microorganisms as potential growth promoters of banana. Biocontrol 53541-553.

[9] Hao G, Du X, and Zhao F. (2010). Fungal endophytes induced abscissic acid is required for flavonoid accumulation in suspension cell of Ginkgo bibloba. Biotechnology Letter, 32 305-314.

[10] Pragya, Singh SK, Misra RS, Ranjan JK. (2012). In vitro shoot regeneration from cormel derived callus of gladiolus and biohardening of plantlets. Indian $J$ Biotech. 11 99-104.

[11] Harish S, Kavino M, Kumar N, Saravana kumar D, Soorianatha sundaram K, Samiyappan R (2008): Biohardening with Plant Growth Promoting Rhizosphere and Endophytic bacteria induces systemic resistance against Banana bunchy top virus. Applied Soil Ecology 39 (2) 187-200.

[12] El Hassan SA and Gowen SR. (2006). Formulation and delivery of the bacterial antagonistic Bacillus subtilis for management of lentil vascular wilt caused by Fusarium oxysporum f sp. lentis. Journal of Phytopathology. 154 148-155.

[13] Trivedi P, Pandey A and Palani LMS. (2005). Carrier based preparations of plant growth promoting bacteria inoculants suitable for use in cooler regions. World $J$ Microbiol and Biotechnol 21 941-945.

[14] Verma K, Rani A, Saini R. (2011). An efficient plant regeneration system from half seed explants of soybean [Glycine $\max (\mathrm{L}$.$) Merrill] using thidiazuron. Soybean$ Res 8 12-23. 


\section{International Journal of Science and Research (IJSR) \\ ISSN (Online): 2319-7064 \\ Index Copernicus Value (2013): 6.14 | Impact Factor (2015): 6.391}

[15] Chandra S, Bandopadhyay R, Kumar V and Chandra R. (2010). Acclimatization of tissue cultured plantlets: from laboratory to land, Biotechnol Lett, 32 1199-1205.

[16] Kaneda Y, Tabei, Y, Nishimura S, Harada K, Akihama T, Kitamura K. (1997). Combination of thidiazuron and basal media with low salt concentrations increases the frequency of shoot organogenesis in soybeans [Glycine $\max ($ L.) Merr.]. Plant Cell Rep 17 8-12.

[17] Verma K, Rani A, Saini R. (2009). Direct organogenesis and plantlet regeneration from cotyledonary node of Indian soybean [Glycine max (L.) Merrill cultivars. Soybean Res 7 8-15.

[18] Verma K, Saini R, Rani A. (2014). Recent advances in the regeneration and genetic transformation of soybean. J Innovative Biology. 1 015-026.
[19] Panigrahi S, Lakshmi K.A, Venkadeshvaralu Y, Umesh N. (2015). Biohardening of Micropropagated Plants with PGPR and Endophytic Bacteria Enhances the Protein Content. Biotechnology and Bioforensics 51-59.

[20] Ravindra Kumar K. Singh K P and Raju D V S. (2014). Symbiotic Effect of Arbuscular Mycorrhizal Fungi on Growth and Flowering of Micropropagated Plants of Chrysanthemum (Chrysanthemum dendranthemum). Intern J Bio-resource and Stress Management. 5(3) 369-374.

[21] Ngamau C N. Matiru V N. Tani A. Muthuri C W. (2014). Potential Use of Endophytic Bacteria as Biofertilizer for Sustainable Banana (Musa Spp) Production. Afr J Horti and Sci. 8 1-11.

Table 1: Effect of hormones on plantlet regeneration of halfseed explants with embryonic axis of soybean variety (JS335)

\begin{tabular}{|c|c|c|c|c|c|}
\hline $\begin{array}{c}\text { Hormone } \\
\text { Concentrations } \\
(\mu \mathrm{M})\end{array}$ & $\begin{array}{c}\text { Percentage of } \\
\text { Response }(\%)\end{array}$ & $\begin{array}{c}\text { No. of } \\
\text { Shoots }\end{array}$ & $\begin{array}{c}\text { Length of } \\
\text { Shoots }(\mathrm{cms})\end{array}$ & No. of Roots & Length of Roots (cms) \\
\hline Control & $46 \mathrm{~d}$ & $05.6 \pm 0.88^{\mathrm{d}}$ & $3.1 \pm 0.34 \mathrm{~d}$ & $6.6 \pm 1.20 \mathrm{~d}$ & $1.3 \pm 0.14 \mathrm{~d}$ \\
1 & $76 \mathrm{c}$ & $14.6 \pm 2.02^{\mathrm{b}}$ & $4.8 \pm 0.20 \mathrm{c}$ & $11.6 \pm 1.20 \mathrm{c}$ & $1.6 \pm 0.15 \mathrm{c}$ \\
TDZ $(15)+\mathrm{NAA}$ & $83 \mathrm{~b}$ & $15.0 \pm 1.52 \mathrm{~b}$ & $5.5 \pm 0.15 \mathrm{~b}$ & $13.6 \pm 1.20 \mathrm{~b}$ & $2.3 \pm 0.17 \mathrm{a}$ \\
5 & $\mathbf{8 6 a}$ & $\mathbf{2 0 . 6 \pm 0 . 8 8 a}$ & $\mathbf{9 . 0 \pm 0 . 7 8 a}$ & $14.6 \pm 0.88 \mathrm{a}$ & $2.3 \pm 0.14 \mathrm{a}$ \\
$\mathbf{1 0}$ & & & & & \\
\hline 1 & $63 \mathrm{c}$ & $11.0 \pm 0.57 \mathrm{~b}$ & $6.4 \pm 0.17 \mathrm{a}$ & $15.0 \pm 1.15 \mathrm{~b}$ & $2.7 \pm 0.14 \mathrm{~b}$ \\
TDZ $(15)+\mathrm{IBA}$ & $66 \mathrm{~b}$ & $12.0 \pm 1.15 \mathrm{a}$ & $5.3 \pm 1.21 \mathrm{~b}$ & $\mathbf{1 8 . 6 \pm 0 . 8 8 a}$ & $\mathbf{2 . 9 \pm 0 . 1 8 a}$ \\
$\mathbf{5}$ & $83 \mathrm{a}$ & $11.0 \pm 1.15 \mathrm{~b}$ & $4.2 \pm 0.23 \mathrm{c}$ & $14.3 \pm 2.33 \mathrm{c}$ & $2.6 \pm 0.11 \mathrm{c}$ \\
10 & $66 \mathrm{a}$ & $8.3 \pm 2.02 \mathrm{~b}$ & $3.5 \pm 0.26 \mathrm{c}$ & $6.0 \pm 1.52 \mathrm{a}$ & $1.6 \pm 0.17 \mathrm{a}$ \\
\hline 1 & $60 \mathrm{c}$ & $11.6 \pm 3.28 \mathrm{a}$ & $5.3 \pm 0.06 \mathrm{a}$ & $2.0 \pm 0.00 \mathrm{c}$ & $1.5 \pm 0.27 \mathrm{~b}$ \\
BAP (15)+NAA & $63 \mathrm{~b}$ & $8.3 \pm 2.96 \mathrm{~b}$ & $4.6 \pm 0.08 \mathrm{~b}$ & $5.6 \pm 0.33 \mathrm{~b}$ & $1.5 \pm 0.24 \mathrm{~b}$ \\
5 & & & & & \\
\hline 10 & $63 \mathrm{~b}$ & $6.6 \pm 1.45 \mathrm{~b}$ & $4.1 \pm 0.12 \mathrm{~b}$ & $13.3 \pm 1.20 \mathrm{~b}$ & $2.4 \pm 0.06 \mathrm{a}$ \\
BAP (15)+IBA & $70 \mathrm{a}$ & $8.0 \pm 1.15 \mathrm{a}$ & $5.3 \pm 0.13 \mathrm{a}$ & $15.6 \pm 2.33 \mathrm{a}$ & $2.0 \pm 0.30 \mathrm{~b}$ \\
5 & $70 \mathrm{a}$ & $6.6 \pm 1.20 \mathrm{~b}$ & $3.7 \pm 0.20 \mathrm{c}$ & $11.3 \pm 0.88 \mathrm{c}$ & $1.7 \pm 0.12 \mathrm{c}$ \\
\hline 10 & & & & & \\
\hline
\end{tabular}

Data represented as the mean value \pm standard error from the three experiments with 10 explants Mean followed by different letters (DMRT) in the same column differ significantly $\mathrm{P}<0.05$.

Table 2: Effect of Bacillus subtilis inoculation on survival of in vitro raised plantlets of soybean (JS335) for biohardening.

\begin{tabular}{|c|c|c|c|c|c|c|c|c|c|}
\hline \multirow{2}{*}{$\begin{array}{c}\text { Bacillus subtilis } \\
\text { Optical Density } \\
(600 \mathrm{~nm})\end{array}$} & \multirow{2}{*}{$\begin{array}{l}\text { Percentage of } \\
\text { response }(\%)\end{array}$} & \multicolumn{2}{|c|}{ Number of Shoots } & \multicolumn{2}{|c|}{ Length of Shoots (cms) } & \multicolumn{2}{|c|}{ No of Roots } & \multicolumn{2}{|c|}{ Length of Roots $(\mathrm{cms})$} \\
\hline & & $\begin{array}{c}\text { Before } \\
\text { treatment }\end{array}$ & $\begin{array}{c}\text { After } \\
\text { treatment }\end{array}$ & $\begin{array}{c}\text { Before } \\
\text { treatment }\end{array}$ & $\begin{array}{c}\text { After } \\
\text { treatment }\end{array}$ & $\begin{array}{c}\text { Before } \\
\text { treatment }\end{array}$ & $\begin{array}{c}\text { After } \\
\text { treatment }\end{array}$ & $\begin{array}{c}\text { Before } \\
\text { treatment }\end{array}$ & $\begin{array}{c}\text { After } \\
\text { treatment }\end{array}$ \\
\hline Control & 5 & $9.3 \pm$ & $15.0 \pm 0.5 \mathrm{~d}$ & $3.2 \pm 0.4 \mathrm{~d}$ & $3.5 \pm 0.3 \mathrm{~d}$ & $2.0 \pm 0.0 \mathrm{~d}$ & $5.3 \pm 0.4 \mathrm{~d}$ & $1.2 \pm 0.1 \mathrm{~d}$ & \\
\hline 0.6 & 8 & $13.3 \pm$ & 26.0 & $9.6 \pm 0.8 \mathrm{a}$ & $21.0 \pm 0.5 \mathrm{a}$ & $6.0 \pm 0.5 \mathrm{a}$ & $12.3 \pm$ & $.3 \mathrm{a}$ & $\pm .01 \mathrm{a}$ \\
\hline 0 & & & & & & $6.3 \pm$ & & & \\
\hline 1.0 & $70 \mathrm{c}$ & $12.0 \pm 0.5 \mathrm{c}$ & $22.0 \pm 0.2 \mathrm{c}$ & $4.2 \pm 0.2 \mathrm{c}$ & $16.7 \pm 0.8 \mathrm{c}$ & $4.6 \pm 0.3 \mathrm{c}$ & $6.0 \pm 0.5 \mathrm{c}$ & $1.3 \pm 0.1 \mathrm{c}$ & $2.0 \pm 0.3 \mathrm{c}$ \\
\hline
\end{tabular}

10 plantlets were taken and experiments were replicated thrice, after 20 days of treatment results were noticed and analysed the data by SPSS

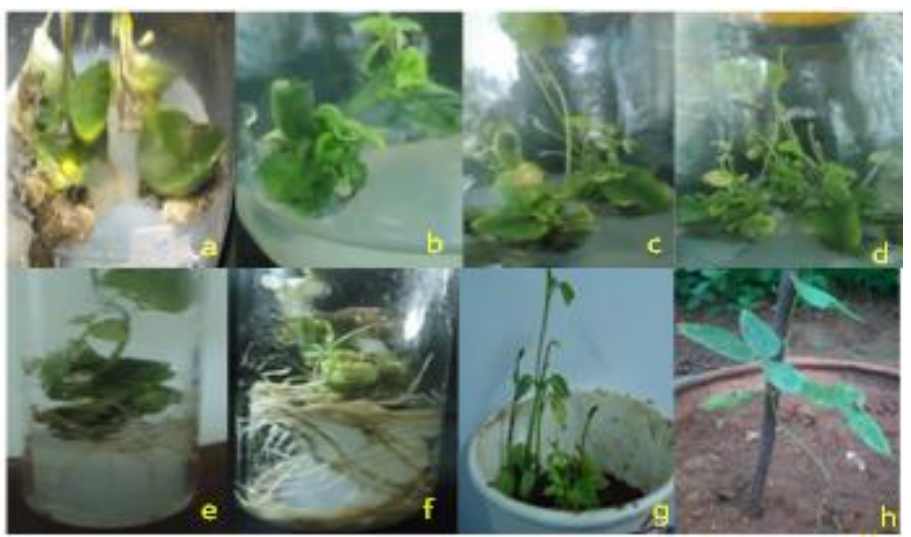

Volume 5 Issue 5, May 2016 www.ijsr.net 


\section{International Journal of Science and Research (IJSR) \\ ISSN (Online): 2319-7064 \\ Index Copernicus Value (2013): 6.14 | Impact Factor (2015): 6.391}

Figure 1: Plantlet regeneration of soybean (JS335) variety by using half seed explant

a) Half seed explants inoculated in MS medium and shoot initiation after 10 days; b. Multiplication of shoot after 15 days; c. Multiplication of shoot after 20 days in the MS medium fortified with TDZ and IBA $(10 \mu \mathrm{M})$; d. Multiplication of shoot after 20 days in the MS medium fortified with TDZ and NAA $(10 \mu \mathrm{M})$; e. Root initiation in the MS medium fortified with TDZ and NAA $(10 \mu \mathrm{M})$; f. Root initiation in the MS medium fortified with TDZ and IBA $(10 \mu \mathrm{M})$; g. Hardening of Plantlets in papercups; h. Biohardened plantlets after application of Bacillus subtilis after 20 days.

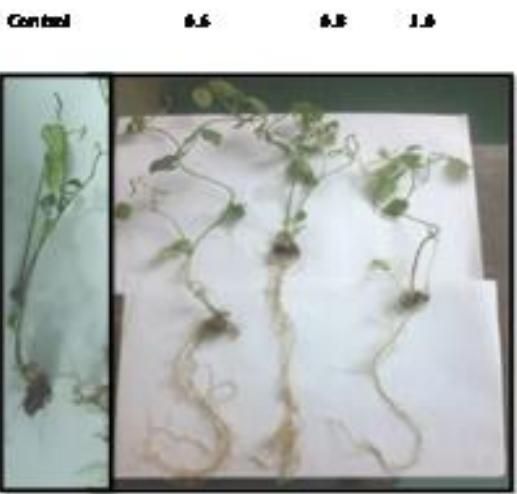

Figure 2: Effect of Bacillus subtilis inoculum for Biohardening.

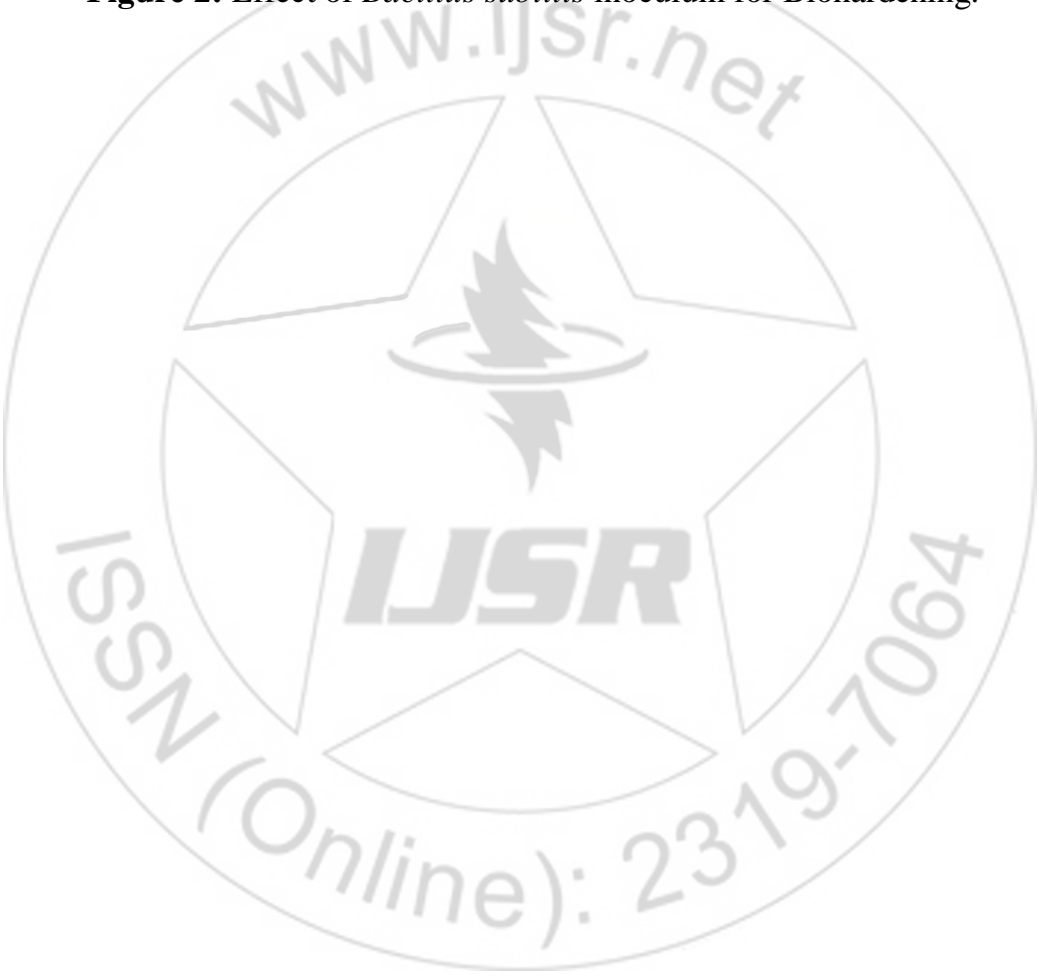

